International Journal of

Environmental Research and

Public Health

ISSN 1660-4601

www.mdpi.com/journal/ijerph

Article

\title{
Histological Lesions, Cell Cycle Arrest, Apoptosis and T Cell Subsets Changes of Spleen in Chicken Fed Aflatoxin-contaminated Corn
}

\author{
Xi Peng ${ }^{1}$, Keying Zhang ${ }^{2}{ }^{*}$, Shiping Bai ${ }^{2}$, Xuemei Ding ${ }^{2}$, Qiufeng Zeng ${ }^{2}$, Jun Yang ${ }^{2}$, \\ Jing Fang ${ }^{1}$ and Kejie Chen ${ }^{1}$
}

1 College of Veterinary Medicine, Sichuan Agricultural University, Sichuan 625014, China;

E-Mails: pengxi197313@163.com (X.P.); fangjing4109@163.com (J.F.); ckj930@126.com (K.C.)

2 Key Laboratory for Animal Disease-Resistance Nutrition of China Ministry of Education, Institute of Animal Nutrition, Sichuan Agricultural University, Sichuan 625014, China;

E-Mails: shipingbai@aliyun.com (S.B.); dingxuemei0306@163.com (X.D.);

zqf@sicau.edu.com (Q.Z.); yangjun0612@163.com (J.Y.)

* Author to whom correspondence should be addressed; E-Mail: zkeying@ sicau.edu.cn;

Tel./Fax: +86-835-2885-630.

Received: 11 July 2014; in revised form: 31 July 2014 / Accepted: 5 August 2014 /

Published: 20 August 2014

\begin{abstract}
The purpose of this study was to evaluate the effects of corn naturally contaminated with aflatoxin B1 and aflatoxin B2 on pathological lesions, apoptosis, cell cycle phases and $\mathrm{T}$ lymphocyte subsets of spleen, and to provide an experimental basis for understanding the mechanism of aflatoxin-induced immunosuppression. A total of 900 COBB500 male broilers were randomly allocated into five groups with six replicates per group and 30 birds per replicate. The experiment lasted for 6 weeks and the five dietary treatments consisted of control, 25\% contaminated corn, 50\% contaminated corn, $75 \%$ contaminated corn and $100 \%$ contaminated corn groups. The histopathological spleen lesions from the contaminated corn groups was characterized as congestion of red pulp, increased necrotic cells and vacuoles in the splenic corpuscle and periarterial lymphatic sheath. The contaminated corn intake significantly increased relative weight of spleen, percentages of apoptotic splenocytes, induced cell cycle arrest of splenocytes, increased the percentages of $\mathrm{CD}^{+} \mathrm{CD}^{+} \mathrm{T}$ cells and decreased the ratios of $\mathrm{CD} 3{ }^{+} \mathrm{CD} 4^{+}$to $\mathrm{CD} 3{ }^{+} \mathrm{CD} 8^{+}$. The results suggest that AFB-induced immunosuppression maybe closely related to the lesions of spleen.
\end{abstract}


Keywords: aflatoxin; broiler; pathological lesion; apoptosis; cell cycle

\section{Introduction}

Mycotoxins are secondary toxic fungal metabolites which cause important health problems in human and animals [1]. Aflatoxins are a type of mycotoxin which usually contaminate feed ingredients during storage. Among identified aflatoxins, aflatoxin B1 (AFB1) is the predominant form, which presents the highest hepatotoxic and carcinogenic effects [2] and is classified as a Group I carcinogen to humans by the International Agency for Research on Cancer [3]. The toxic and carcinogenic effects of AFB1 are closely linked with its biotransformation [4]. The active intermediate, AFB1-exo-8, 9-epoxide, can bind with DNA to form the predominant trans-8, 9-dihydro-8-(N7-guanyl)-9-hydroxy-AFB1 (AFB1-N7-Gua) adduct which causes DNA lesions [5]. Previous studies proved that aflatoxins had a range of negative effects on poultry health. Besides carcinogenic effects [6], acute or chronic aflatoxicosis in poultry birds results in poor performance [7], immunosuppression, and increased susceptibility to disease [6,8].

As the largest peripheral lymphoid tissue of the body, the spleen is of vital importance in the whole immune function [9]. Previous studies showed that AFB1 caused tissue damage of spleen in rats [10], induced bio-molecular oxidative damage and decreased cell proliferation in spleen mononuclear cells (SMC) [11,12], induced mutations of splenic lymphocytes from rats [13], and decreased the number of $\mathrm{CD}^{+}$and $\mathrm{CD}^{+} \mathrm{T}$ cells in mice [14].

Although lymphocytic depletion of spleen in broilers and ducklings exposed to AFB has been reported [15,16], there are no systemic studies on spleen damage in broilers exposed to AFB. AFB1 22 is commonly found along with AFB2 in corn in the southwest of China, so the objectives of this study were to evaluate the pathological lesion, apoptosis and $\mathrm{T}$ cell subsets of spleen in broilers fed on corn naturally contaminated with AFB1 and AFB2. The results could aid in understanding the underlying basis for the immunosuppression attributable to aflatoxin.

\section{Materials and Methods}

\subsection{Animals, Diets and Study Design}

Nine hundred 1-day-old Cobb500 chickens were randomly assigned to five experimental groups with six replicates per group and 30 birds per replicate. The birds were housed in the cages for 42 days at the Animal Nutrition Institute of Sichuan Agricultural University in China. Chicks were provided the corresponding diets and water ad libitum throughout the 42 days of experimentation. Room lights were set on a 24-h continuous schedule, temperature was initially maintained at $31{ }^{\circ} \mathrm{C}$ and gradually lowered by $2{ }^{\circ} \mathrm{C}$ each week until $21^{\circ} \mathrm{C}$, and relative humidity were maintained between $65 \%$ and $67 \%$. The animal experiment was conducted in accordance with guidelines approved by Animal Health and Care Committee of Sichuan Agricultural University.

The control animals were fed with the corn-soybean basal diet. Nutritional requirements of the diet were adequate according to National Research Council (1994) and Agricultural Trade Standardization 
of China (NY/T33-2004). The composition and nutrient levels of the diet were described previously [17]. The basal control diet was not contaminated with AFB1 and AFB2. The four treated groups were given diets in which the ratio of naturally contaminated corn as a substitute for normal corn was $25 \%, 50 \%, 75 \%$, and $100 \%$, respectively. By the method of high performance liquid chromatography (Agilent 1100, Forster City, CA, USA), the contents of mycotoxins, including AFB1, AFB2, AFG1, AFG2, T-2 toxin, deoxynivalenol (DON), zearalenone (ZEN), ochratoxin A (OTA), and fumonisin B1 (FB1) was detected as described previously [18]. The detection limits of above mycotoxins were $2 \mu \mathrm{g} / \mathrm{kg}$ for AFB1, $0.8 \mu \mathrm{g} / \mathrm{kg}$ for AFB2, $2.5 \mu \mathrm{g} / \mathrm{kg}$ for AFG1, $1.5 \mu \mathrm{g} / \mathrm{kg}$ for AFG2, $100 \mu \mathrm{g} / \mathrm{kg}$ for T-2 toxin, $300 \mu \mathrm{g} / \mathrm{kg}$ for DON, $100 \mu \mathrm{g} / \mathrm{kg}$ for ZEN, $30 \mu \mathrm{g} / \mathrm{kg}$ for OTA, and $200 \mu \mathrm{g} / \mathrm{kg}$ for FB1 [19].

The results showed that naturally contaminated corn used in the diet was mainly contaminated with AFB1 and AFB2. The AFB1 contents in diets were $16.3 \sim 82.4 \mu \mathrm{g} / \mathrm{kg}$ in the starter period and $34.3 \sim 134 \mu \mathrm{g} / \mathrm{kg}$ in the grower period (Table 1). The AFB2 concentrations in diets were 3.15 14.2 and $6.17 \sim 23.6 \mu \mathrm{g} / \mathrm{kg}$ in the starter and grower periods, respectively. The contents of AFB1 and AFB2 were different due to different storage time and contaminated degree of corn (Table 1). The contents of other mycotoxins (including AFG1, AFG2, DON, ZEA, OTA, T-2 toxin, and FB1) were below the limit of detection.

At 21 and 42 days of age during the experiment, birds were sacrificed; spleens were sampled for the pathological observation and the determination of the cell cycle, apoptosis, and $\mathrm{T}$ cell subsets by flow cytometry.

Table 1. Mycotoxins concentrations in diet and corn (air-dry basis $\mu \mathrm{g} / \mathrm{kg}$ ).

\begin{tabular}{|c|c|c|c|c|c|c|c|}
\hline Diet $^{1}$ & Control & $25 \%$ & $50 \%$ & $75 \%$ & $100 \%$ & Control Corn & Contaminated Corn \\
\hline \multicolumn{8}{|l|}{$1 \sim 21 \mathrm{~d}$} \\
\hline $\mathrm{AFB}_{1}$ & $\mathrm{ND}^{2}$ & 16.3 & 36.9 & 45.6 & 82.4 & ND & 149.6 \\
\hline $\mathrm{AFB}_{2}$ & $\mathrm{ND}$ & 3.15 & 6.38 & 7.86 & 14.2 & ND & 24.2 \\
\hline \multicolumn{8}{|l|}{$22 \sim 42 \mathrm{~d}$} \\
\hline $\mathrm{AFB}_{1}$ & ND & 34.3 & 69.3 & 95.2 & 134 & ND & 229 \\
\hline $\mathrm{AFB}_{2}$ & ND & 6.17 & 12.1 & 17 & 23.6 & ND & 37.8 \\
\hline $\begin{array}{l}\text { Notes: }^{1} \\
50 \%= \\
\text { contami }\end{array}$ & ntrol $=\mathrm{dic}$ & t with & ontrol & orn; 25 & $=$ diet & $\begin{array}{l}\text { with } 25 \% \text { natural } \\
\text { n: } 75 \%=\text { diet }\end{array}$ & $\begin{array}{l}\text { y contaminated corn; } \\
\text { with } 75 \% \text { naturally } \\
\text { corn; }{ }^{2} \mathrm{ND}=\text { not }\end{array}$ \\
\hline
\end{tabular}

\subsection{Relative Weight of Spleen}

At 21 and 42 days of age during the experiment, after the body weight was weighed, six birds in each group were euthanized and necropsied. The spleen was dissected from each chick, and weighed after dissecting connective tissue around the organ. Relative weight of organ was calculated through the following formula: 


\subsection{Pathological Observation}

After weighing, spleens were fixed in $4 \%$ buffered formaldehyde and routinely processed in paraffin. Thin sections $(5 \mu \mathrm{m})$ of each tissue were sliced from each block and mounted on glass. Slides were stained with hematoxylin and eosin Y. Histological slides were examined on an Olympus light microscope.

\subsection{Cell Cycle Phase Detection}

At 21 and 42 days of age during the experiment, six birds in each group were euthanized. The spleen was dissected from each chick and immediately minced with surgical scissors. The cell suspension was filtered through a 300-mesh nylon mesh, washed twice with $0.1 \mathrm{M}$ (pH 7.4) cold phosphate buffered saline (PBS), and then resuspended cells in PBS at a concentration of $1 \times 10^{6}$ cells $/ \mathrm{mL}$. The $1 \mathrm{~mL}$ suspension was transferred to a $5-\mathrm{mL}$ culture tube and centrifuged at $200 \times \mathrm{g}$ for $5 \mathrm{~min}$. The supernatant was discarded, and $1 \mathrm{~mL}$ PI staining solution $(5 \mu \mathrm{L} / \mathrm{mL}$ propidium iodide, $0.5 \%$ Triton X-100, 0.5\% RNase, PBS) was added. The cells were gently vortexed and incubated for $20 \mathrm{~min}$ at room temperature $\left(25^{\circ} \mathrm{C}\right)$ in the dark. $2 \mathrm{~mL}$ PBS were added and centrifugal elutriation performed once. The supernatant was discarded. The cells were re-suspended in $0.5 \mathrm{~mL}$ PBS and the cell phases were analyzed by flow cytometry (FACSCalibur, BD, Franklin Lake, NJ, USA).

\subsection{Apoptosis Detection}

At 21 and 42 days of age during the experiment, six birds in each group were euthanized. Spleen was dissected from each chick and immediately minced with surgical scissors. The cell suspension was filtered through a 300-mesh nylon mesh, washed twice with cold PBS and then resuspended cells in $1 \times$ binding buffer (Cat. No. 51-66121E, BD Pharmingen, Santiago, CA, USA) at a concentration of 1 $\times 10^{6}$ cells $/ \mathrm{mL}$. One hundred microliters of the solution was transferred to a $5-\mathrm{mL}$ culture tube, and then $5 \mu \mathrm{L}$ of Annexin V-FITC (Cat. No. 51-65874X, BD Pharmingen, Santiago, CA, USA) and $5 \mu \mathrm{L}$ of PI (Cat. No. 51-66211E, BD Pharmingen, Santiago, CA, USA) were added. The cells were gently vortexed and incubated for $15 \mathrm{~min}$ at room temperature $\left(25^{\circ} \mathrm{C}\right)$ in the dark. Four hundred microliters of $1 \times$ binding buffer was added to each tube and analyzed by flow cytometry (FACSCalibur) within $1 \mathrm{~h}$.

\subsection{Cell T Cell Subsets Detection by Flow Cytometry}

The spleens of six birds in each group were taken to determine the percentages of $\mathrm{CD}^{+}$, $\mathrm{CD}^{+} \mathrm{CD} 4^{+}, \mathrm{CD}^{+} \mathrm{CD}^{+} \mathrm{T}$ cells by the flow cytometry method and calculate the $\mathrm{CD} 4^{+} / \mathrm{CD} 8^{+}$ratio at 21 and 42 days of age during the experiment. Splenic single cell suspension was prepared by gently cutting each spleen and then filtering through nylon gauze. Splenic single cell suspension was centrifuged at $200 \times \mathrm{g}$ for $5 \mathrm{~min}$. The supernatant was discarded and lymphocytes were collected. The cell concentration was diluted to $1.0 \times 10^{6}$ cells $/ \mathrm{mL}$ with phosphate-buffered saline (PBS). $100 \mu \mathrm{L}$ cell suspensions were transferred to another centrifuge tube, and respectively stained with $10 \mu \mathrm{L}$ mouse anti-chicken CD3-SPRD (Cat. No. 8200-13, SouthernBiotech, Birmingham, AL, USA), mouse 
anti-chicken CD4-FITC (Cat. No. 8210-02, SouthernBiotech, Birmingham, AL, USA) and mouse anti-chicken CD8a-RPE (Cat. No. 8220-09, SouthernBiotech, Birmingham, AL, USA) for 15-20 min at room temperature, and then $2 \mathrm{~mL}$ PBS added and centrifugal elutriation performed once. The supernatant was discarded. The cells were resuspended in $0.5 \mathrm{~mL}$ PBS and determined using a BD FACS Calibur flow cytomyter.

\section{Results}

\subsection{Relative Weight of Spleen}

As described in Figure 1, relative weight of spleen was significantly higher in $100 \%$ contaminated group than in control group at 21 and 42 days of age $(p<0.01$ or $p<0.05)$, but no significant differences were observed among the control, 25\%, 50\% and 75\% groups although there was an increase tendency. The results indicated that high level of simultaneous AFB1 and AFB2-contaminated diet intake increased splenic relative weight in broilers.

Figure 1. Effects of corn naturally contaminated with AFB1 and AFB2 on relative weight of broilers spleen. Data are presented with the means \pm standard deviation $(n=6)$. When compared with the control group, * means $p<0.05$. ** means $p<0.01$.

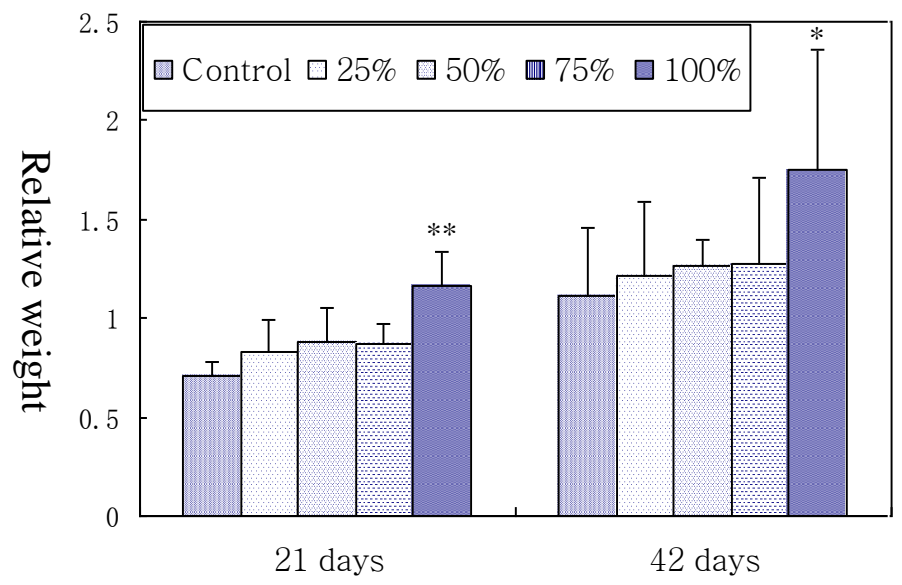

\subsection{Pathological Lesions}

Macroscopically, the spleens were dark red in control group, but they were light red in the 50\%, $75 \%$ and $100 \%$ groups (Figure 2), and spleen was increased in size, especially in the $100 \%$ group. The most obvious changes were observed at 21 days of age.

Histopathologically, there were no obvious lesions in the spleens of the $25 \%$ group when compared with those of control group (Figure 3A) at 21 and 42 days of age. Congestion of red pulp became obvious as the dietary mycotoxin level was increased (Figure 3B). Compared with the control group (Figure 3C), necrotic cells and vacuoles in the splenic corpuscle and periarterial lymphatic sheath of the spleen were gradually increased in number in the 50\%, 75\%, and 100\% groups (Figure 3D-F) at 21 days of age. Histological lesions of spleen in mycotoxin contaminated corn groups were all alleviated at 42 days of age. 
Figure 2. Gross changes in the size and colour of the spleen in the chickens at 21 days of age. From left to right: spleen in control group, $25 \%, 50 \%, 75 \%$ and $100 \%$ groups.

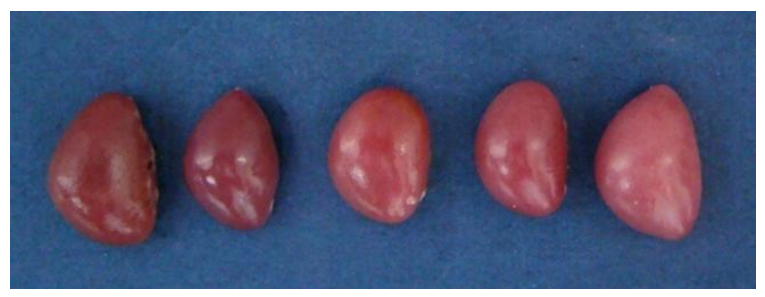

Figure 3. Photomicrographs of hematoxylin and eosin stained chicken spleen section. (A) shows the normal histological structure of control group; (B) shows that congestion of red pulp (*) is obvious in $100 \%$ group. At 21 days of age, when compared with those of control group (C), nuclear debris and vacuoles (arrows) are gradually increased in the spleen of chickens in 50\%, 75\% and 100\% groups (D-F, respectively).

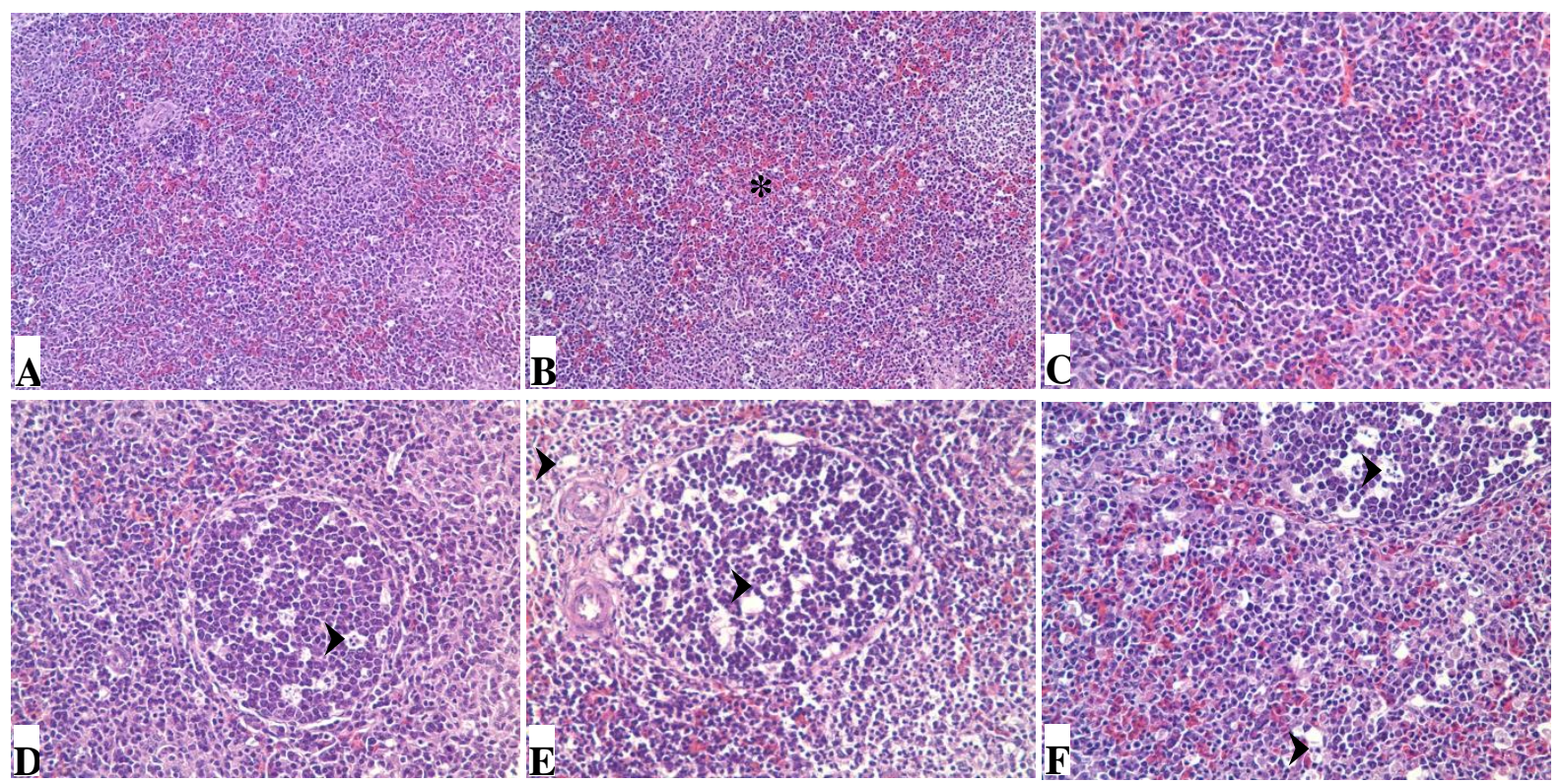

\subsection{Cell Cycle Phase-Distribution of Splenocytes}

At 21 days of age, the percentage of $\mathrm{G}_{0} \mathrm{G}_{1}$ splenocytes in the $100 \%$ group was lower than in the control group, and the proliferating index (PI) value in100\% group was higher than control group ( $p<0.05$ ). Changes of the $\mathrm{G}_{2} \mathrm{M}$ phase were obvious; the percentages of $\mathrm{G}_{2} \mathrm{M}$ phase splenocytes were increased in a dose-dependent manner. However, at 42 days of age, when compared with control group, the percentages of splenocytes in $\mathrm{G}_{0} \mathrm{G}_{1}$ phase were obviously increased in the $75 \%$ and $100 \%$ groups $(p<0.01$ or $p<0.05$ ); the percentages of splenocytes in S phase and PI value were decreased $\left(p<0.01\right.$ or $p<0.05$ ) in $75 \%$ and $100 \%$ groups; the percentage of $\mathrm{G}_{2} \mathrm{M}$ phase splenocytes was decreased in $100 \%$ group. The results showed that $\mathrm{G}_{2} \mathrm{M}$ and $\mathrm{G}_{0} \mathrm{G}_{1}$ phase blockage could be observed in chicken spleen at 21 and 42 days of age respectively. The results were shown in Table 2 and Figure 4. 
Table 2. Effect of AFB-contaminated corn on cell cycle phase distribution of spleen in chickens.

\begin{tabular}{cccccc}
\hline Time & Group & $\mathbf{G}_{\mathbf{0}} \mathbf{G}_{\mathbf{1}}$ Phase (\%) & $\mathbf{G}_{\mathbf{2}} \mathbf{M}$ Phase (\%) & S Phase (\%) & PI \\
\hline \multirow{6}{*}{21 days } & Control & $82.04 \pm 2.87$ & $9.05 \pm 1.51$ & $8.91 \pm 1.40$ & $17.96 \pm 2.87$ \\
& $25 \%$ & $80.95 \pm 3.27$ & $9.49 \pm 1.56$ & $9.55 \pm 1.72$ & $19.05 \pm 3.27$ \\
& $50 \%$ & $79.60 \pm 1.17$ & $10.71 \pm 0.74 *$ & $9.69 \pm 0.82$ & $20.40 \pm 1.17$ \\
& $75 \%$ & $79.32 \pm 1.86$ & $11.68 \pm 1.28 * *$ & $9.00 \pm 1.02$ & $20.68 \pm 1.86$ \\
& $100 \%$ & $78.37 \pm 0.80 *$ & $12.88 \pm 0.50 * *$ & $8.74 \pm 0.38$ & $21.63 \pm 0.80 *$ \\
\hline \multirow{6}{*}{42 days } & Control & $84.56 \pm 0.67$ & $7.69 \pm 0.73$ & $7.75 \pm 0.41$ & $15.44 \pm 0.67$ \\
& $25 \%$ & $84.47 \pm 2.12$ & $7.50 \pm 0.99$ & $8.02 \pm 1.14 \mathrm{~d}$ & $15.53 \pm 2.12$ \\
& $50 \%$ & $85.52 \pm 1.65$ & $7.25 \pm 0.91$ & $7.23 \pm 1.00$ & $14.45 \pm 1.65$ \\
& $75 \%$ & $86.80 \pm 1.32 *$ & $6.81 \pm 0.64$ & $6.39 \pm 0.84 *$ & $13.20 \pm 1.32 *$ \\
& $100 \%$ & $87.42 \pm 0.70 * *$ & $6.25 \pm 0.22 * *$ & $6.33 \pm 0.84 *$ & $12.58 \pm 0.70 * *$ \\
\hline
\end{tabular}

Notes: Data are presented with the means \pm standard deviation $(n=6)$. When compared with the control group, * means $p<0.05, * *$ means $p<0.01$.

Figure 4. DNA histograms of splenocytes' cell cycles. The percentage of $\mathrm{G}_{2} \mathrm{M}$ phase is higher in $50 \%$ and $100 \%$ group than in control group at 21 days of age. The percentage of $\mathrm{S}$ phase is lower in $50 \%$ and $100 \%$ group than in control group at 42 days of age.

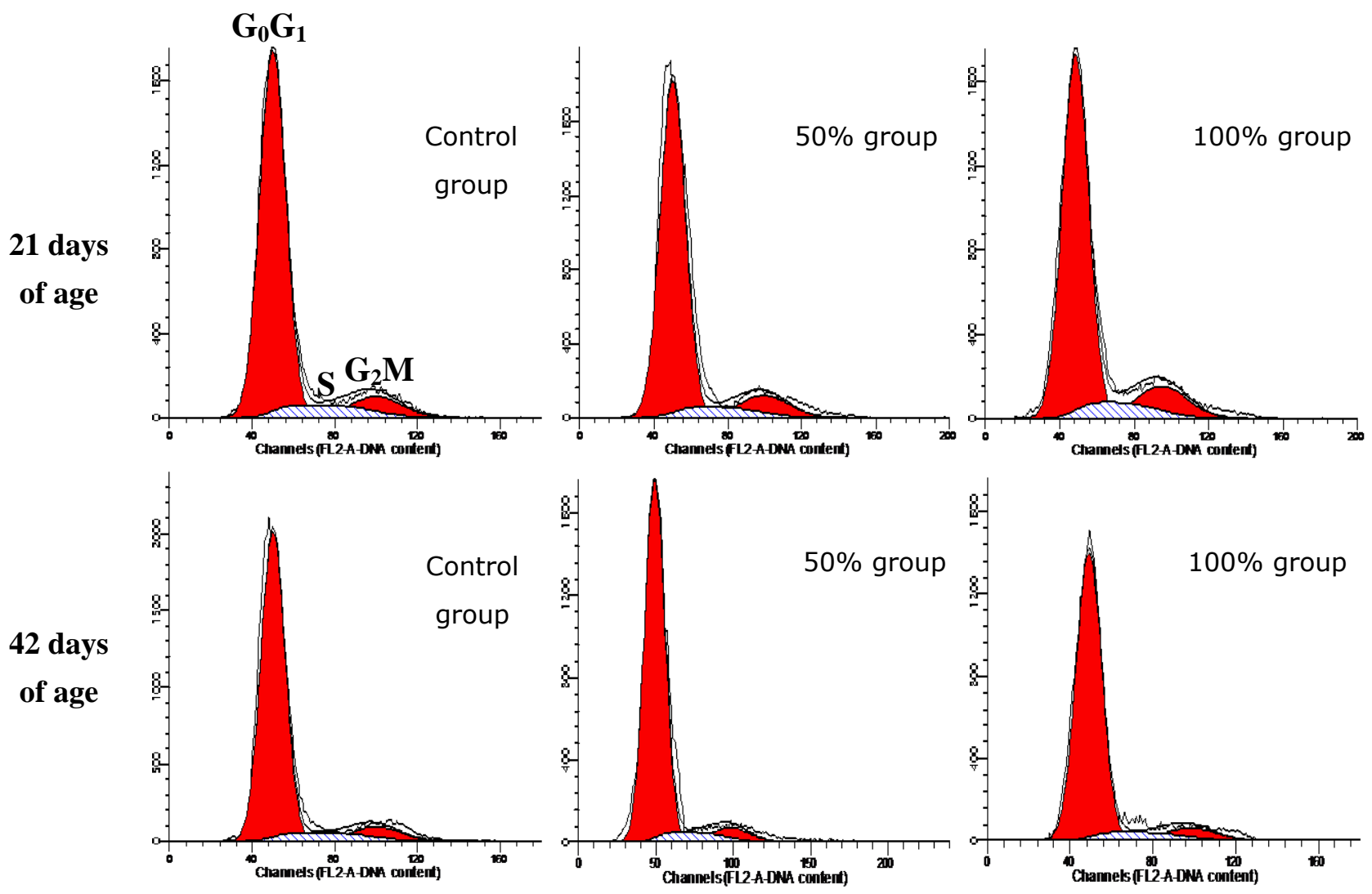




\subsection{Annexin V-FITC Staining Assay by Flow Cytometry}

As shown in Figure 5, the percentages of apoptotic splenocytes increased as the dietary aflatoxin level increased. The percentages of apoptotic cells in the $25 \%, 50 \%, 75 \%$, and $100 \%$ groups were significantly higher $(p<0.01)$ than those in the control group, and the percentages of apoptotic cells in the $75 \%$ and $100 \%$ groups were significantly higher $(p<0.01)$ than those in the $25 \%$ and $50 \%$ groups at 21 days of age. At 42 days of age, compared with the control group, the percentages of apoptotic splenocytes in the $50 \%, 75 \%$, and $100 \%$ groups were increased $(p<0.01$ or $p<0.05)$. A quadrantal diagram analyzed by flow cytometer showed that more splenocytes in AFB-contaminated groups were undergoing apoptosis (Figure 5).

Figure 5. The upper left histogram shows the effects of corn naturally contaminated with $\mathrm{AFB}_{1}$ and $\mathrm{AFB}_{2}$ on apoptosis of splenocytes. Data are presented with the means \pm standard deviation $(n=6)$. When compared with the control group, * means $p<0.05$. ** means $p<0.01$. Quadrantal diagram showed that a minor percentage of cells in control group are undergoing apoptosis and increased percentage of cells in 50\% and $100 \%$ groups is undergoing apoptosis.
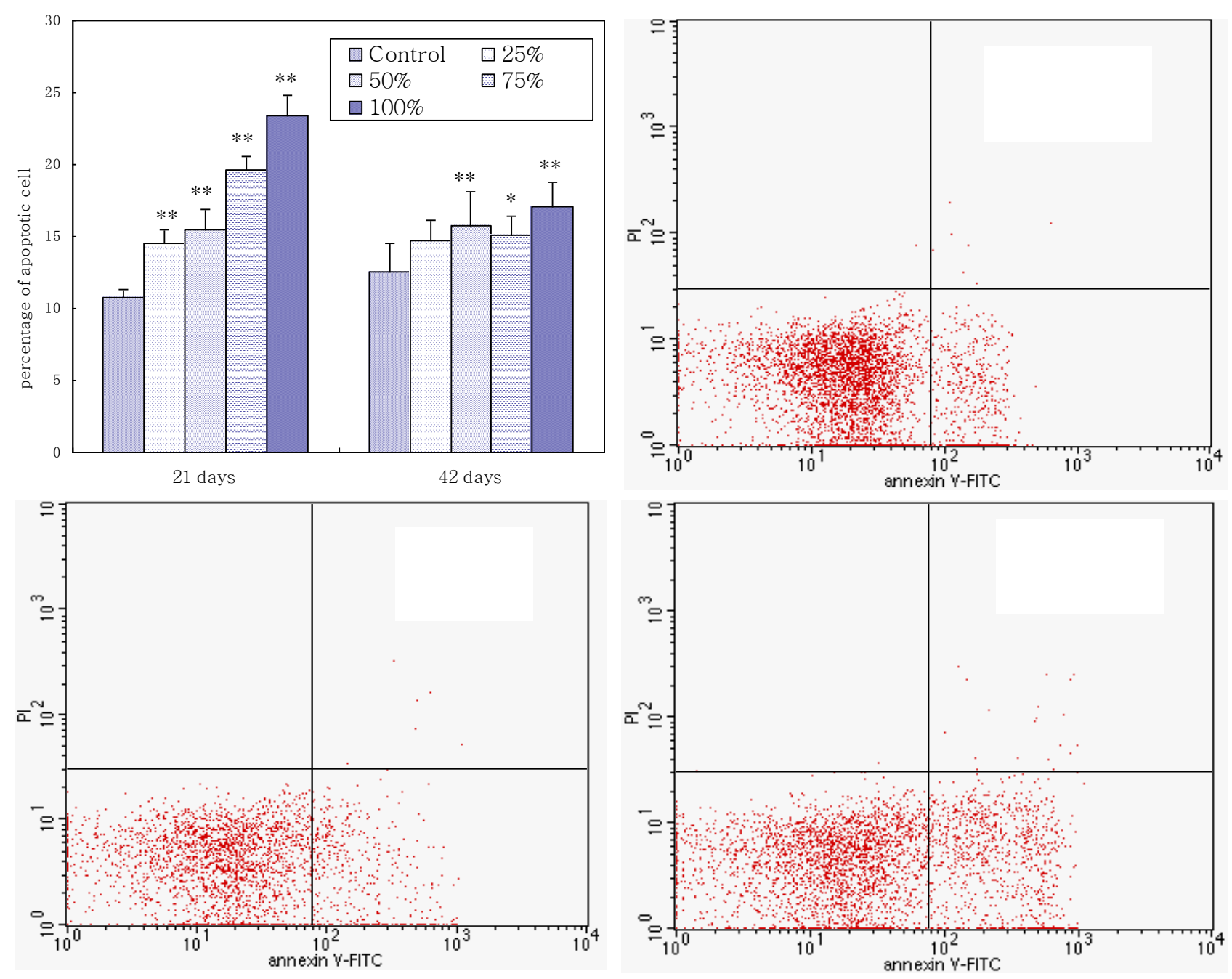


\subsection{Splenic T Cell Subsets}

At 21 days of age, the percentages of $\mathrm{CD}^{+} \mathrm{CD} 8^{+} \mathrm{T}$ cells in the $75 \%$ and $100 \%$ groups were much higher $(p<0.05)$ and the ratios of $\mathrm{CD}^{+} \mathrm{CD} 4^{+} \mathrm{T}$ cells to $\mathrm{CD} 3^{+} \mathrm{CD} 8^{+} \mathrm{T}$ cells were much lower $(p<0.05$ or $p<0.01)$ than those in the control group. At 42 days of age, compared with the control group, the percentage of $\mathrm{CD}^{+} \mathrm{CD}^{+} \mathrm{T}$ cells in the $100 \%$ groups was significant increased $(p<0.05)$, and the ratios of $\mathrm{CD}^{+} \mathrm{CD}^{+}$to $\mathrm{CD} 3^{+} \mathrm{CD} 8^{+}$were significant decreased $(p<0.05)$ (Table 3 ).

Table 3. Changes of splenic T-cell subsets (\%).

\begin{tabular}{|c|c|c|c|c|c|}
\hline Time & Items & $\mathrm{CD3}^{+}$ & $\mathrm{CD3}^{+} \mathrm{CD4}^{+}$ & $\mathrm{CD3}^{+} \mathrm{CDB}^{+}$ & $\mathrm{CD3}^{+} \mathrm{CD4}^{+} / \mathrm{CD3}^{+} \mathrm{CD8}^{+}$ \\
\hline \multirow{5}{*}{21 days } & Control & $\begin{array}{c}64.73 \pm \\
3.05\end{array}$ & $34.67 \pm 2.08$ & $27.47 \pm 2.19$ & $1.27 \pm 0.08$ \\
\hline & $25 \%$ & $\begin{array}{c}65.38 \pm \\
4.85\end{array}$ & $33.02 \pm 6.06$ & $32.34 \pm 7.39$ & $1.06 \pm 0.30$ \\
\hline & $50 \%$ & $\begin{array}{c}64.13 \pm \\
5.85\end{array}$ & $33.98 \pm 4.84$ & $32.17 \pm 5.91$ & $1.09 \pm 0.30$ \\
\hline & $75 \%$ & $\begin{array}{c}62.26 \pm \\
5.11\end{array}$ & $35.39 \pm 5.68$ & $36.04 \pm 5.49 *$ & $0.98 \pm 0.07 *$ \\
\hline & $100 \%$ & $\begin{array}{c}59.57 \pm \\
4.77 \\
\end{array}$ & $30.19 \pm 1.96$ & $34.34 \pm 2.09 *$ & $0.88 \pm 0.08 * *$ \\
\hline \multirow{5}{*}{42 days } & Control & $\begin{array}{c}77.00 \pm \\
5.26\end{array}$ & $31.83 \pm 5.32$ & $34.94 \pm 3.48$ & $0.91 \pm 0.07$ \\
\hline & $25 \%$ & $\begin{array}{c}74.95 \pm \\
4.83\end{array}$ & $30.11 \pm 5.47$ & $34.94 \pm 6.59$ & $0.89 \pm 0.25$ \\
\hline & $50 \%$ & $\begin{array}{c}77.34 \pm \\
2.94\end{array}$ & $29.34 \pm 6.67$ & $37.20 \pm 2.92$ & $0.79 \pm 0.19$ \\
\hline & $75 \%$ & $\begin{array}{c}75.20 \pm \\
3.81\end{array}$ & $31.37 \pm 3.92$ & $36.59 \pm 2.44$ & $0.86 \pm 0.14$ \\
\hline & $100 \%$ & $\begin{array}{c}79.06 \pm \\
5.13\end{array}$ & $26.65 \pm 4.08$ & $43.72 \pm 5.91 * *$ & $0.62 \pm 0.12 *$ \\
\hline
\end{tabular}

Notes: Data are presented with the means \pm standard deviation $(n=6)$. When compared with the control group, * means $p<0.05, * *$ means $p<0.01$.

\section{Discussion}

The spleen is known as the principal pheripheral immune organ. In the present study, the relative weight of spleen was used to judge the extent of spleen lesions. The relative weight of the spleen in birds fed with corn naturally contaminated with $\mathrm{AFB}_{1}$ and $\mathrm{AFB}_{2}$ increased, which was similar to the results from other researchers [20-22]. According to histopathological observation, the relative weight increase seems to be due to the congestion of red pulp in the spleen. As known, splenic nodules and the periarterial lymphatic sheath are where B lymphocytes and $\mathrm{T}$ lymphocyte gather and mature, respectively [23]. In the present study, histopathological results showed that necrotic cells in the splenic corpuscle and periarterial lymphatic of the spleen were gradually increased in number in the $50 \%, 75 \%$, and $100 \%$ groups, which indicated that excessive necrosis of B cells and $\mathrm{T}$ cells would finally impair the immune function of the spleen. 
In the present study, the percentages of splenocytes in $\mathrm{G}_{2} \mathrm{M}$ phase increased in a dose-dependent manner at 21 days of age. Previous studies showed that AFB-induced cell cycle arrest occurred at different phases depending on the cell type. Thomas et al. reported that aflatoxin B1 treatment can lead to an accumulation of chicken thymocytes in $\mathrm{G}_{2} \mathrm{M}$ phase in vitro [24]; but others researchers found that $\mathrm{AFB}_{1}$ significantly increased the S-phase cell population in murine macrophases [25] and human bronchial epithelial cells [26] in vitro. The results of the present study suggested that more than $36.9 \mathrm{mg} / \mathrm{kg} \mathrm{AFB}_{1}$ combined with $6.38 \mathrm{mg} / \mathrm{kg} \mathrm{AFB}_{2}$ could induce $\mathrm{G}_{2} \mathrm{M}$ phase and $\mathrm{G}_{0} \mathrm{G}_{1}$ phase arrest in chicken splenocytes at 21 and 42 days of age, respectively, which could lead to cell cycle blockage, inhibit the proliferation of splenocytes, drive cells into apoptosis and accordingly decrease the numbers of functional immunocyte in the spleen. Why were the splenocytes arrested in different cell cycle phase at different periods? The mechanisms of cell cycle arrest induced by dietary $\mathrm{AFB}_{1}$ and $\mathrm{AFB}_{2}$ should be further evaluated in the future study.

Apoptosis is a mode of programmed cell death, which allows elimination of unnecessary cells to maintain tissue homeostasis [27]. However, it has been also proven that defective apoptotic processes are implicated in an extensive variety of diseases [28], and excessive apoptosis are actively involved in immunosuppression in various circumstances [29]. In our study, increased apoptotic splenocytes were observed in the AFB-contaminated groups by flow cytometry, and this result was in agreement with the histological observations, which showed that increased nuclear debris was present in the spleens of chicken exposed to AFB contaminated diets. Previous report showed that $\mathrm{AFB}_{1}$ was able to induce apoptosis in hepatocytes, bone marrow cells and lung cells, or human bronchial epithelial cells [30-32]. These results partly revealed the mechanisms of AFB-induced immunosuppression. The up-regulation of apoptotic splenocytes induced by $\mathrm{AFB}_{1}$ and $\mathrm{AFB}_{2}$ are associated with the following factors: (a) oxidative stress of splenocytes induced by aflatoxins [33]; (b) increase of the Bax/Bcl-2 ratio, caspase-3, and caspase- 9 caused by $\mathrm{AFB}_{1}$ led to cellular apoptosis via a process that involves mitochondrial damage [34-36].

$\mathrm{T}$ lymphocytes are responsible for cell-mediated immunity and are further classified according to their expression of cell surface proteins. CD3 molecular is the surface marker of mature T cells, most $\mathrm{CD} 4^{+} \mathrm{T}$ cells are helper $\mathrm{T}$ cells, and $\mathrm{CD} 8^{+} \mathrm{T}$ cells are cytotoxic $\mathrm{T}$ cells [37]. Previous studies showed that the percentage of $\mathrm{CD}^{+}$peripheral blood T cells was decreased [38], and the percentages of CD4 ${ }^{+}$ T-cells and $\mathrm{CD}^{+}$T-cells of splenic lymphocytes were decreased in mice exposed to $\mathrm{AFB}_{1}$ [39]. Contrary to these results, our study showed that the percentages of $\mathrm{CD} 3^{+} \mathrm{CD} 8^{+} \mathrm{T}$ cells in spleen were increased in a dose-response manner in the four AFB-contaminated groups at the same time, The $\mathrm{CD}^{+} / \mathrm{CD}^{+}$ratios were decreased because of the significant increase of the $\mathrm{CD} 3^{+} \mathrm{CD} 8^{+} \mathrm{T}$ cells. $\mathrm{CD} 8^{+}$ $\mathrm{T}$ cells have been shown to play an important role in the host's defense against malignancies [40]. $\mathrm{CD}^{+} \mathrm{T}$ cell protection mediated by its ability to specific target host cells compromised by microbial infection or oncogenic transformation [41,42]. Previous studies proved that aflatoxins present carcinogenic effects [2], and the carcinogenic potency of AFB has been observed in many species of animals, including nonhuman primates, rodents, birds and fish [2,43,44]. Therefore, the increase of $\mathrm{CD}^{+} \mathrm{T}$ cells may be related to the carcinogenic effects of AFB and autoregulation of the antitumor $\mathrm{CD}^{+} \mathrm{T}$ cell response. 


\section{Conclusions}

From the results of this study, together with the above discussion, we conclude that pathological changes, increased apoptotic cells, cell cycle blockage and up-regulated $\mathrm{CD} 8^{+} \mathrm{T}$ cells occur in the spleen in chicks after feeding with corn contaminated with $\mathrm{AFB}_{1}$ and $\mathrm{AFB}_{2}$. The results suggested that one of the mechanisms of AFB-induced immunosuppression is splenic lesions.

\section{Acknowledgments}

This study was supported by a China Postdoctoral Foundation supported project (20110491733), and the Specific Research Support Program for the Academic Sustentation Research Team in Sichuan Agricultural University.

\section{Author Contributions}

Keying Zhang and Xi Peng had the original idea for the study and carried out the research with all the co-authors. Xi Peng and Shiping Bai were responsible for recruitment of research participants and overall arrangement of study. Xuemei Ding and Qiufeng Zeng carried out animal experiments, histological observation, and data collection. Jun Yang, Jing Fang, and Kejie Chen were responsible for the flow cytometry experiments and data analyses. Xi Peng drafted the manuscript, which was revised by all authors. All authors read and approved the final manuscript.

\section{Conflicts of Interest}

The authors declare no conflict of interest.

\section{References}

1. Bryden, W.L. Mycotoxins in the food chain: Human health implications. Asia Pac. J. Clin. Nutr. 2007, 16, 95-101.

2. Wogan, G.N. Aflatoxins as risk factors for hepatocellular carcinoma in humans. Cancer Res. 1992, 52, 2114s-2118s.

3. International Agency for Research on Cancer. IARC Monographs on the Evaluation of Carcinogenic Risks to Humans; World Health Organization: Lyon, France, 2002; pp. 171-175.

4. Wu, H.C.; Wang, Q.; Yang, H.I.; Ahsan, H.; Tsai, W.Y.; Wang, L.Y.; Chen, S.Y.; Chen, C.J.; Santella, R.M. Aflatoxin B1 exposure, hepatitis B virus infection, and hepatocellular carcinoma in Taiwan. Cancer Epidem. Biomar. 2009, 18, 846.

5. Wild, C.P.; Turner, P.C. The toxicology of aflatoxins as a basis for public health decisions. Mutagenesis 2002, 17, 471-481.

6. Rawal, S.; Kim, J.E.; Coulombe, R., Jr. Aflatoxin B1 in poultry: Toxicology, metabolism and prevention. Res. Vet. Sci. 2010, 89, 325-331. 
7. Magnoli, A.P.; Monge, M.P.; Miazzo, R.D.; Cavaglieri, L.R.; Magnoli, C.E.; Merkis, C.I.; Cristofolini, A.L.; Dalcero, A.M.; Chiacchiera, S.M. Effect of low levels of aflatoxin B1 on performance, biochemical parameters, and aflatoxin B1 in broiler liver tissues in the presence of monensin and sodium bentonite. Poult. Sci. 2011, 90, 48-58.

8. Khan, W.A.; Khan, M.Z.; Khan, A.; Hussain, I. Pathological effects of aflatoxin and their amelioration by vitamin E in White Leghorn layers. Pak. Vet. J. 2010, 30, 155-162.

9. Altamura, M.; Caradonna, L.; Amati, L.; Pellegrino, N.M.; Urgesi, G.; Miniello, S. Splenectomy and sepsis: The role of the spleen in the immune-mediated bacterial clearance. Immunopharmacol. Immunotoxicol. 2001, 23, 153-161.

10. Hinton, D.M.; Myers, M.J.; Raybourne, R.A.; Francke, C.S.; Sotomayor, R.E.; Shaddock, J.; Warbritton, A.; Chou, M.W. Immunotoxicity of aflatoxin B1 in rats: Effects on lymphocytes and the inflammatory response in a chronic intermittent dosing study. Toxicol. Sci. 2003, 73, 362-377.

11. Mary, V.S.; Theumer, M.G.; Arias, S.L.; Rubinstein, H.R. Reactive oxygen species sources and biomolecular oxidative damage induced by aflatoxin B1 and fumonisin B1 in rat spleen mononuclear cells. Toxicology 2012, 302, 299-307.

12. Theumer, M.G.; Lopez, A.G.; Masih, D.T.; Chulze, S.N.; Rubinstein, H.R. Immuno-biological effects of AFB1 and AFB1-FB1 mixture in experimental subchronic mycotoxicoses in rats. Toxicology 2003, 186, 159-170.

13. Morris, S.M.; Aidoo, A.; Chen, J.J.; Chou, M.W.; Casciano, D.A. Aflatoxin B1-induced Hprt mutations in splenic lymphocytes of fischer 344 rats: Results of an intermittent feeding trial. Mutat. Res. 1999, 423, 33-38.

14. Sabourin, P.J.; Price, J.A.; Casbohm, S.L.; Perry, M.R.; Tuttle, R.S.; Rogers, J.V.; Rowell, K.S.; Estep, J.E.; Sabourin, C.L. Evaluation of acute immunotoxicity of aerosolized aflatoxin B1 in female C57BL/6N mice. J. Immunotoxicol. 2006, 3, 11-20.

15. Méndez-Albores, A.; Del Río-García, J.C.; Moreno-Martínez, E. Decontamination of aflatoxin duckling feed with aqueous citric acid treatment. Anim. Feed Sci. Tech. 2007, 135, 249-262.

16. Ortatatli, M.; Oğuz, H.; Hatipoğlu, F.; Karaman, M. Evaluation of pathological changes in broilers during chronic aflatoxin (50 and $100 \mathrm{ppb})$ and clinoptilolite exposure. Res. Vet. Sci. 2005, 78, 61-68.

17. Yang, J.; Bai, F.; Zhang, K.; Lv, X.; Bai, S.; Zhao, L.; Peng, X.; Ding, X.; Li, Y.; Zhang, J. Effects of feeding corn naturally contaminated with $\mathrm{AFB}_{1}$ and $\mathrm{AFB}_{2}$ on performance and aflatoxin residues in broilers. Czech. J. Anim. Sci. 2012, 57, 506-515.

18. Yang, J.; Bai, F.; Zhang, K.; Bai, S.; Peng, X.; Ding, X.; Li, Y.; Zhang, J.; Zhao, L. Effects of feeding corn naturally contaminated with aflatoxin B1 and B2 on hepatic functions of broilers. Poult. Sci. 2012, 91, 2792-2801.

19. Administration of Quality and Technology Supervision of Sichuan Province. Official Standard of Administration of Quality and Technology Supervision of Sichuan Province of PRC, Determination of Aflatoxin B1, B2, G1, G2, T-2 Toxin, Deoxynicalenol, Zearalenone, Ochratoxin, Fumonisin B1 with HPLC; People's Government of Sichuan Province: Chengdu, China, 2010. (In Chinese) 
20. Edrington, T.S.; Kubena, L.F.; Harvey, R.B.; Rottinghaus, G.E. Influence of a superactivated charcoal on the toxic effects of aflatoxin or T-2 toxin in growing broilers. Poult. Sci. 1997, 76, 1205-1211.

21. Rosa, C.A.; Miazzo, R.C.; Magnoli, M.; Salvano, S.; Chiacchiera, M.; Frrero, S.; Saenz, M.; Carvalho, E.C.; Dalcero, A. Evaluation of the efficacy of bentonite from the south of Argentina to ameliorate the toxic effects of aflatoxin in broilers. Poult. Sci. 2001, 80, 139-144.

22. Solcan, C.; Gogu, M.; Floristean, V.; Oprisan, B.; Solcan, G. The hepatoprotective effect of sea buckthorn (Hippophae rhamnoides) berries on induced aflatoxin B1 poisoning in chickens. Poult. Sci. 2013, 92, 966-974.

23. Riddell, C. Lymphoid System; Allen Press Inc.: Kansas, KC, USA, 1987.

24. Scott, T.R.; Rowland, S.M.; Rodgers, R.S.; Bodine, A.B. Genetic selection for aflatoxin B1 resistance influences chicken T-cell and thymocyte proliferation. Dev. Comp. Immunol. 1991, 15, 383-391.

25. Bianco, G.; Russo, R.; Marzocco, S.; Velotto, S.; Autore, G.; Severino, L. Modulation of macrophage activity by aflatoxins B1 and B2 and their metabolites aflatoxins M1 and M2. Toxicon 2012, 59, 644-650.

26. Yang, X.; Zhang, Z.; Wang, X.; Wang, Y.; Zhang, X.; Lu, H.; Wang, S. Cytochrome P450 2 A13 enhances the sensitivity of human bronchial epithelial cells to aflatoxin B1-induced DNA damage. Toxicol. Appl. Pharm. 2013, 270, 114-121.

27. Barreto Filho, J.B.; Marques Júnior, A.P. Histological aspects of Zebu Cow's placenta. Arq. Bras. Med. Vet. Zootec. 1993, 45, 385-393.

28. Hetts, S.W. To die or not to die: An overview of apoptosis and its role in disease. J. Am. Med. Assoc. 1998, 279, 300-307.

29. Sun, E.W.; Shi, Y.F. Apoptosis: The quiet death silences the immune system. Pharmacol. Therapeut. 2001, 92, 135-145.

30. Meki, A.R.; Abdel-Ghaffar, S.K.; El-Gibaly, I. Aflatoxin B1 induces apoptosis in rat liver: Protective effect of melatonin. Neuro. Endocrinol. Lett. 2001, 22, 417-426.

31. Hanumantharao, G.R.; Ekta, K.; Vishwajeet, R.; Dwarakanat, B.S.; Virinder, S.P.; Smita, M.; Adhikari, J.S.; Yogesh, K.T.; Sanjay, G.; Mridula, B.; et al. Acetoxy-4-Methylcoumarins confer differential protection from aflatoxin B1-induced micronucei and apoptosis in lung and bone marrow cells. Mutat. Res. 2001, 494, 31-40.

32. Yang, X.J.; Lu, H.Y.; Li, Z.Y.; Bian, Q.; Qiu, L.L.; Li, Z.; Liu, Q.; Li, J.; Wang, X.J.; Wang, S. Cytochrome P450 2A13 mediates Aflatoxin B1 induced cytotoxicity and apoptosis in human bronchial epithelial cells. Toxicology 2012, 300, 138-148.

33. Wang, F.Y.; Shu, G.; Peng, X.; Fang, J.; Chen, K.J.; Cui, H.M.; Chen, Z.L.; Zuo, Z.C.; Deng, J.L.; Geng, Y.; et al. Protective effects of sodium selenite against aflatoxin B1-Induced oxidative stress and apoptosis in broiler spleen. Inter. J. Env. Res. Pub. Heal. 2013, 7, 2834-2844.

34. Duan, X.X.; Ou, J.S.; Li, Y.; Su, J.J.; Ou, C.; Yang, C.H.; Yue, F.; Ban, K.C. Dynami expression of apoptosis-related genes during development of laboratory hepatocellular carcinoma and its relation to apoptosis. World J. Gastroenterol. 2005, 11, 4740-4744. 
35. Van Vleet, T.R.; Watterson, T.L.; Klein, P.J.; Coulombe, R.A., Jr. Aflatoxin B1 alters the expression of p53 in cytochrome P450-expressing human lung cells. Toxicol. Sci. 2006, 89, 399-407.

36. Chen, K.J.; Shu, G.; Peng, X.; Fang, J.; Cui, H.M.; Chen, J.; Wang, F.Y.; Chen, Z.L.; Zuo, Z.C.; Deng, J.L.; et al. Protective role of sodium selenite on histopathological lesions, decreased T-cell subsets and increased apoptosis of thymus in broilers intoxicated with aflatoxin B1. Food Chem. Toxicol. 2013, 59, 308-316.

37. Pavelka, M.; Roth, J. Functional Ultrastructure-Atlas of Tissue Biology and Pathology; Springer: New York, NY, USA, 2005.

38. Tomková, I.; Ševčiková, Z.; Levkut, M.; Revajová, V.; Čonková, E.; Laciaková, A.; Lenhardt, L. Effect of aflatoxin $\mathrm{B} 1$ on $\mathrm{CD} 3 \mathrm{~T}$ cells and alkaline phosphatase in the intestine of mice. Mycopathologia 2002, 154, 15-19.

39. Sabourin, P.J.; Price, J.A.; Casbohm, S.L. Perry, M.R.; Tuttle, R.S.; Rogers, J.V.; Rowell, K.S.; Estep, J.E.; Sabourin, C.L. Evaluation of acute immunotoxicity of aerosolized aflatoxin B1 in female C57BL/6N mice. J. Immunotoxicol. 2006, 3, 11-20.

40. Xie, Y.; Wang, L.; Freywald, A.; Qureshi, M.; Chen, Y.; Xiang, J. A novel T cell-based vaccine capable of stimulating long-term functional CTL memory against B16 melanoma via CD40L signaling. Cell. Mol. Immunol. 2012, 10, 72-77.

41. Williams, M.A.; Bevan, M.J. Effector and memory CTL differentiation. Annu. Rev. Immunol. 2007, 25, 171-192.

42. Prado-Garcia, H.; Romero-Garcia, S.; Aguilar-Cazares, D.; Meneses-Flores, M.; Lopez-Gonzalez, J.S. Tumor-induced $\mathrm{CD}^{+} \mathrm{T}$-cell dysfunction in lung cancer patients. Clin. Dev. Immunol. 2012, doi:10.1155/2012/741741.

43. Benford, D.; Leblanc, J.; Setzer, R.W. Application of the margin of exposure (MoE) approach to substances in food that are genotoxic and carcinogenic: Example: Aflatoxin B1 ( $\left.\mathrm{AFB}_{1}\right)$. Food Chem. Toxicol. 2010, 48, S34-S41.

44. Bailey, G.S.; Williams, D.E.; Wilcox, J.S.; Loveland, P.M.; Coulombe, R.A.; Hendricks, J.D. Aflatoxin B1 carcinogenesis and its relation to DNA adduct formation and adduct persistence in sensitive and resistant salmonid fish. Carcinogenesis 1988, 9, 1919-1926.

(C) 2014 by the authors; licensee MDPI, Basel, Switzerland. This article is an open access article distributed under the terms and conditions of the Creative Commons Attribution license (http://creativecommons.org/licenses/by/3.0/). 